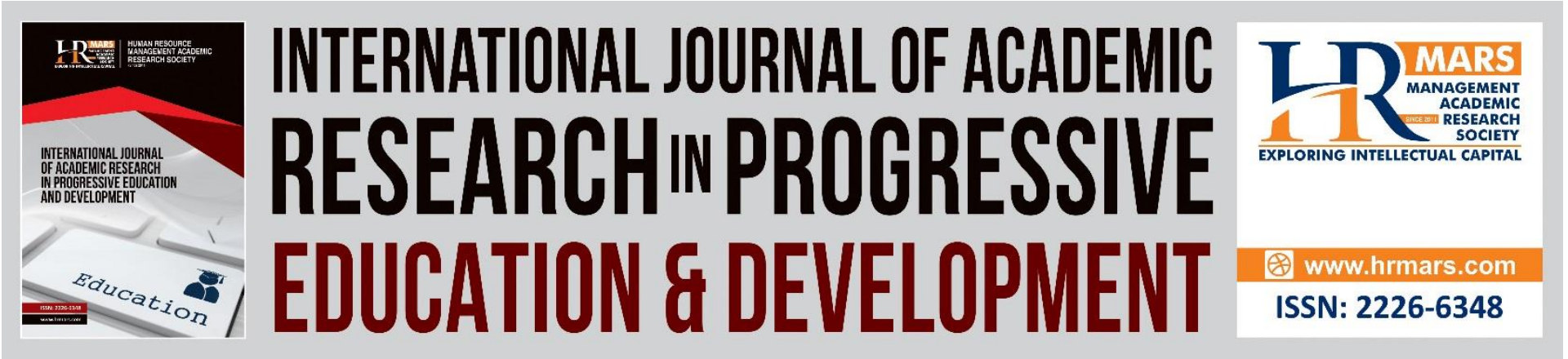

\title{
Student Satisfaction of University Service Quality in Malaysia: A Review
}

\author{
Norlaili Mohd Yusof, Soaib Asimiran, Suhaida Abdul Kadir
}

To Link this Article: http://dx.doi.org/10.6007/IJARPED/v11-i1/10985 DOI:10.6007/IJARPED/v11-i1/10985

Received: 12 November 2021, Revised: 16 December 2021, Accepted: 09 January 2022

Published Online: 29 January 2022

In-Text Citation: (Yusof et al., 2022)

To Cite this Article: Yusof, N. M., Asimiran, S., \& Kadir, S. A. (2022). Student Satisfaction of University Service Quality in Malaysia: A Review. International Journal of Academic Research in Progressive Education and Development, 11(1), 677-688.

Copyright: (C) 2022 The Author(s)

Published by Human Resource Management Academic Research Society (www.hrmars.com)

This article is published under the Creative Commons Attribution (CC BY 4.0) license. Anyone may reproduce, distribute, translate and create derivative works of this article (for both commercial and non-commercial purposes), subject to full attribution to the original publication and authors. The full terms of this license may be seen

at: http://creativecommons.org/licences/by/4.0/legalcode

Vol. 11(1) 2022, Pg. 677 - 688

Full Terms \& Conditions of access and use can be found at http://hrmars.com/index.php/pages/detail/publication-ethics 


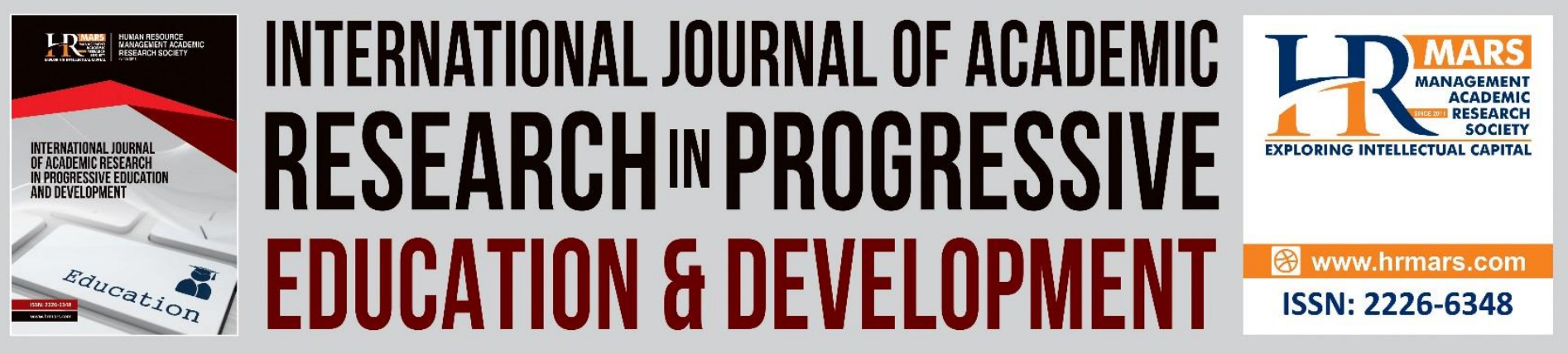

\title{
Student Satisfaction of University Service Quality in Malaysia: A Review
}

\author{
Norlaili Mohd Yusof ${ }^{1}$, Soaib Asimiran², Suhaida Abdul Kadir ${ }^{3}$ \\ 1,2Department of Foundations of Education, ${ }^{3}$ Department of Science and Technical \\ Education, Faculty of Educational Studies, Universiti Putra Malaysia, 43400 UPM Serdang, \\ Selangor Darul Ehsan, Malaysia. Correspondence concerning this article should be \\ addressed to Norlaili Mohd Yusof, Department of Foundations of Education, Faculty of \\ Educational Studies, Universiti Putra Malaysia, Selangor Darul Ehsan, Malaysia. \\ Email: lieyf1148@yahoo.com
}

\begin{abstract}
The attraction of new students and the retention of current students have become an imperative topic in many institutions as rivalry between institutions is growing worldwide. In order to survive, expand, and remain competitive, educational institutions must recognise the importance of service quality and student satisfaction. Therefore, providing quality education services is a high priority for all these institutions. Institutions need to truly fulfil the needs of students in order to deliver top quality services to students and recognise how cognitive factors contribute to student satisfaction. Positive expectations of service quality by current students will contribute towards positive images of the organisations, and to overall satisfaction. Thus, the purpose of this paper is to analyse the standard of university service in the satisfaction of students with a sound empirical finding. Refereed articles and conference papers were used to gather the data. The first section of the paper addresses the satisfaction of students, the quality of university service, and the second section describes the empirical results of previous research in the sense of real world. This research looked at the empirical literature on higher education with the purpose of increasing the present contribution of knowledge. The empirical findings revealed that service quality has an impact on student satisfaction in a variety of study contexts.
\end{abstract}

Keywords: Student Satisfaction, University Service Quality, Education

\section{Introduction}

Education at the university or college level is one of the most critical mechanisms for a nation's personal social and economic growth (Mukhtar et al., 2015). The primary aim of higher education is to produce and disseminate information through innovation and creativity for global growth (Escotet, 2012). Higher education institutions increasingly do their best to set their students at the centre of their activities and become organisations that are "studentoriented" or "student-driven." Also, Fortino (2012) believes that students' prepared minds are produced for higher education purposes. Higher education institutions are therefore progressively understanding and putting greater stress on fulfilling their clients' desires and 
needs, that is, the students (DeShileds, Ali \& Erdener, 2005). Thus, the main reasons for the presence of higher educational institutions are effective completion and advancement of student education. This optimistic trend in higher education indicates that educational institutions understand the importance of student satisfaction in the competitive world (Yusof et al., 2015). In the management of higher education institutions, enhancing students' satisfaction has long been considered a vital strategic aim (Ali et al., 2016; Prakash, 2018). Potential carriers of positive 'word-of-mouth' contact are only happy consumers, allowing each institution to create a safe and sustainable public image.

Service quality and student satisfaction are the essential principles that educational institutions must recognise in order to survive, develop and stay competitive, according to Wael (2015). Higher education institutions perform in the service sector, where the value of delivering quality services is increasingly recognised (Adinegara \& Putra, 2016). Service quality is about meeting and exceeding customer needs (Van Truong et al., 2016). Tegambwage (2017) suggests that the quality of service is based on a contrast between the preferences of consumers prior to using the service and their experience after using the service. Based on this, it is easy to interpret that the quality of service depends on their consumer expectations, since one customer can perceive a high-quality service while another customer perceives low quality service. Nevertheless, many higher education institutions still fail to meet or surpass these standards because of the ongoing expectations of students (Prakash, 2018). Such challenges have motivated higher education institutions to consider the alternatives to enhance service quality effectiveness in order to achieve greater customer satisfaction (Prakash, 2018; Chandra, et al., 2019). The expectations of students regarding service quality related issues may therefore be proven as significant (Neupane \& Devkota, 2017). Numerous studies have been carried out to define the level of university service that affects student satisfaction in higher education institutions.

\section{Student Satisfaction}

Student satisfaction is an emotional reaction to the service experience and a condition felt by a person with a result that meets his or her needs and expectations (Annamdevula, 2017; Lien, 2017). Most generally, student satisfaction refers to their subjective evaluations related to individual performance and educational experience. In this respect, students' experience is not independent on their overall satisfaction, such as college life, because the combination of these experiences influences students' overall satisfaction (Elliott \& Shin, 2002; Letcher \& Neves, 2010).

Student satisfaction is a short-term attitude resulting from an assessment of a student's educational experiences (Elliot \& Healy, 2001). It is a strong antecedent of student loyalty and is the product and consequence of educational system (Navarro, Iglesias \& Torres, 2005).Again, Elliot \& Shin (2002) define student satisfaction as the disposition of learners through subjective evaluation of educational results and experience. According to Mukhtar et al (2015), student satisfaction can be characterised as a function of relative experience level and perceived performance of educational service during the study period. The satisfaction of students can be defined as a short-term attitude resulting from evaluation of educational experience, services and facilities of students. 
According to Abdullah (2006), the satisfaction of students plays a crucial role in the success of universities and can serve as an important instrument to improve the perceived quality of service. Students are also increasingly seen as customers of higher education institutions, which makes the satisfaction of attracting new students to educational institutions a very essential function (Thomas \& Galambo, 2004). It is the duty of higher education institutions to consider the process of fulfilling student satisfaction and to search for ways and methods of measuring student satisfaction (Alves \& Raposo, 2007).

The most important stakeholder for society is the students from educational sector as it utilises the mechanism of quality effects on them by applying the input, method, and output on them. There is a need for stronger bridges between stakeholders from outside the universities (employers, communities, parents) and academic institutions, as the global economy is evolving and the connections among all groups depends on student satisfaction (Khan \& Shaikh, 2011). The satisfaction of students towards the institution directly influences the social elements (student/teacher relationship, administrative relationships, student relationship) and physical factors (modern classroom, library, transportation, computers, WiFi, canteen and support services) (Uka, 2014). The commitment of leader management towards student satisfaction has shown continuous and increased service standards (Mark, 2013).

\section{University Service Quality}

Service quality is the assessment of the service recipient regarding the overall performance of an institution's service delivery. It is a measure of contrasting the preferences of customers with the services offered that influence customer satisfaction (Kang et al., 2004). Alhkami and Alarussi (2016) agree that the standard of service is very essential because clients feelmore appreciated when they perceive that the company is taking steps that meet their standards. Teeroovengadum, Kamalanabhan, and Seebaluck (2016) described service quality as the interpretation of a university's services by the students. According to Asaduzzamanand Rahman (2013), a university's service quality is an aspect of its students' experience as an overall evaluation of the services provided by the university. He defined tangibles as the most important factor in determining the satisfaction of students with the quality of service, including factors related to faculty and climate, namely cleanliness, room temperature, computer laboratory, internet facilities, building appearance, staff appearance, and parking facilities.

Parasuraman et al (1988), SERVQUAL, studied various dimensions of service quality. Five key parameters or dimensions, including tangibility, reliability, responsiveness, assurance and empathy, were involved in SERVQUAL (Lupo, 2013). Tangibility is characterised as the personnel's physical facilities, appearance and equipment (Quinn et al., 2009). Similarly, tangibility is the visible function of SERVQUAL that universities use to increase the satisfaction of foreign students (Panda \&Das 2014). Reliability describes the capacity to regularly and efficiently achieve the exact service required (Brochado, 2009). University staff are therefore considered trustworthy if they deliver the promised services correctly, show care for students by responding promptly and document student records correctly. Responsiveness describes the urge to support foreign students and immediately offers facilities (Gallifa \& Batallé, 2010). This suggests that university employees need to be more attentive, because a timely response will ensure that a student is aware of the inquiry of the students (Sultan \& Wong, 2010). While, assurance is described as the courtesy and knowledge of employees and their 
capability to foster confidence and trust (Quinn et al., 2009; Clewes, 2003). Hasan et al. (2008) stated that assurance is one of the essential dimensions of service quality, which means that courtesy, expertise, and the willingness to establish confidence and trust are the concerns of higher education students. The last dimension is empathy, described by the university as loving, individualised attention provided to its students. Hasan et al. (2008) suggested that the informal and formal method of the students to their lecturer would lead to greater satisfaction with their experience in college.

Meanwhile, Teeroovengadum et al (2016) suggested the HESQUAL Model, consisting of (5) five dimensions to measure service quality, namely the dimensions of administrative quality, physical environment quality, primary education quality, support facilities quality and transformational quality. Administrative quality component refers to the attitudes and behaviours of the employees and administrative processes. The quality of physical environment refers to infrastructure support, the learning environment, and the general infrastructure; four variables, namely curriculum, attitude and conduct, competence and pedagogy, which are the main quality of education. Since the standard of support facilities applies to support facilities, six elements are used to assess them. Next, transformative quality refers to students' growth in terms of self-confidence, analytical thinking, problem solving abilities, and the enhancement of knowledge and skills of the students. In addition, Jain, Sinha and Sahney (2011) defined two significant dimensions, namely programme quality and quality of life to understand the expectations of service quality by students with eight sub-dimensions (academic facility, input quality, non-academic process, support facilities, curriculum, interaction with industry, interaction quality, campus) to represent the specific aspects of a service delivery process. Furthermore, the study by Sharma and Al-Sinawai (2021) explored the effect of service quality on organisational performance by using a questionnaire developed by SERVQUAL modification, comprising five dimensions, such as academic capital, academic competence, development of skills, attitude and responsiveness. The results showed that the three universities offered the same degree of standards of academic services. It was also found that all the five dimensions of academic services standard greatly affected the efficiency of organisation.

\section{Empirical Research Findings}

Each company should consider enhancing the satisfaction of their users with quality service (Kitsios et al., 2019). For all industries, including higher education institutions, a good service quality is important because it will enable the company to achieve its competitive advantages. Any service quality changes that are not focused on the needs of customers would not lead to an increase in customer satisfaction (Sivadas and Baker-Prewitt, 2000). In addition, frustration will cause clients to distribute negative reviews and that will give the company a bad image (Suhaimi et al., 2018). Several studies have shown that customer service quality assessment can impact upon customer satisfaction (Kitsios, et al., 2019; Muhamad, et al., 2018; Rizwan et al., 2015).

Previous studies used (5) dimensions of SERVQUAL to define the effect of service quality on student satisfaction. Barua and Uddin (2021)'s study primarily aimed at examining the relationship between the dimensions of service quality (tangibles, reliability, responsiveness, assurance and empathy) and the satisfaction among 207 students from eight universities. The findings showed that there is a positive relationship between directly observable dimensions of service quality and student satisfaction, and reliability has a major impact on the satisfaction of students. The research also found that responsiveness, assurance, and 
empathy have an insignificant relationship with the satisfaction of students. Similarly, the current research by Lukic and Lukic (2020) among 986 respondents from Western Balkan students assessed the nature of the relationship between perceived service quality and student satisfaction.

Another study by Alsheyadi and Albalushi (2020) examined the interaction among 352 students from 18 higher education institutes in Oman, with regard to tangibles, reliability, assurance, responsiveness and empathy dimensions of service quality on student satisfaction. The findings found that the concrete dimensions of service quality, reliability, assurance, responsiveness and empathy were identified as having a direct impact on student satisfaction. Such evidence was also found in a study conducted by Hassan et al (2019) to establish the relationship between service quality and student satisfaction. A total of 398 students participated in the study. The results showed that the standard of service has a major positive relationship with the satisfaction of students. The findings also indicate that the aspects of empathy and response need to be focused by the employees as the quality of service is crucial when students are involved. The results of this research suggest that a successful partnership between employees and students would increase the satisfaction of students with the services offered. In addition, Kandie's (2018) research on 60 university students in Kenya also proved the influence of service quality on student satisfaction. The results of the research indicate that service quality dimensions such as reliability, assurance, visibility, and response have a positive and important effect on student satisfaction. If students feel comfortable communicating with university employees, believing in the ability of employees to solve problems, and if the employees are willing to support and value students, solve problems quickly and provide the necessary learning facilities for students, it would generate satisfaction for students with the services provided.

In another study to explore the link between service quality and the satisfaction of students at public universities in Kenya et al (2016), it was concluded that the dimensions of service quality had a major impact on student satisfaction. These findings indicate some contradictions when they relate to expectations of the dimension of tangibles in the equation of service quality and how satisfaction may be related to service quality. The study conducted among educational institutions in Malaysia by Turay et al (2017) drew a different conclusion that only a medium-strength association with satisfaction was shown by the responsiveness dimension. In line with these results, Douglas, Douglas, McClelland and Davies (2015) who studied student satisfaction in the United Kingdom's higher education context, concluded that responsiveness from a student's point of view is arguably the most important dimension of quality.

Manik and Sidharta (2017) studied the quality of service among academic institutions in Indonesia and noted that, compared to other dimensions of service quality, student perceptions of the assurance offered by institutions were poor. In comparison, a study conducted in Nigeria to examine student satisfaction with the service quality of libraries in private universities found that perceptual scores correlated with assurance were higher than those of other dimensions of service quality. Based on the data collected from students in business schools in Jordan, it was discovered that assurance has a statistically important relation with student satisfaction (Al-Haddad, Taleb and Badran, 2018). This is due to the fact thatthe expectations of students about the degree of assurance given in their institutions are likely to vary. Saleem et al (2017) addressed the effect of service quality on the level of satisfaction of students. The results showed that, apart from tangibility, other elements of service quality have a substantial effect on the satisfaction of students. This implies that 
students do not rate the school on the basis of architecture and physical appearance, but on the standard of education provided. Another study to explore the link between service quality and the satisfaction of students at public universities in Kenya, Kara, Tanui and Kalai (2016) concluded that the dimensions of service quality have a major impact on student satisfaction. These findings indicate some contradictions when they relate to expectations of the dimension of tangibles in the equation of service quality and how satisfaction may be related to service quality.

In order to determine the relationship between service quality and student satisfaction, Hassan and Kurt, (2019) conducted a study on 120 students from (3) three universities in Mogadishu, Somalia. The results showed that the standard of service has a strong and critical relationship with the satisfaction of students. The dimension of reliability is the dimension that has the greatest relationship with student satisfaction as compared to the other four dimensions, according to the results of the report. This indicates that the consideration provided by the educational institution will increase the satisfaction of the student.

In addition to using SERVQUAL as a service quality dimension, previous studies have used various service quality dimensions, such as in (Annamdevula and Bellamkonda's report, 2016). Teaching, administrative services, internationalisation, instructional facilities, support services, and campus infrastructure are the dimensions of service quality which have been established. The senior students at seven Indian universities illustrate that service quality have a huge effect on student satisfaction. Ali et al (2016) in his study used five service quality metrics, such as academic aspects, non-academic aspects, programme problems, and credibility. The research included 400 foreign students at three Kuala Lumpur public universities and found that student satisfaction is affected by the five dimensions of service quality. Program problems and academic factors mostly impacted student satisfaction by having the highest average value, based on the dimensions of service quality. This indicates that the university has succeeded in enhancing the standard of the core items of higher education sector for academics and programmes.

Furthermore, Mansori et al (2014) in their study used classrooms, security components, libraries, sports facilities, internet services, dormitories, and canteens as a service quality dimension. For the research, a total of 460 students were sampled from (3) three Malaysian public universities. The results of the study showed that service quality has a major positive relationship with the satisfaction of students. The results of the report showed that the satisfaction of the students was influenced by safety aspects, libraries, sports facilities, internet services, dormitories and canteens as the most favoured by students.

The findings from Owino (2013)'s study on 1,089 students in Kenya showed that service quality has a relationship with student satisfaction. The findings suggest that all aspects of service quality such as human component, non-human component, blueprint service and core service (core service) are related to student satisfaction. In addition, Farahmandian et al (2013)'s study used equipment, consulting services, instruction, financial assistants, and cost of analysis as a service quality dimension. This research was carried out on 225 students from Universiti Teknologi Malaysia, Kuala Lumpur. The study's results showed that there is a positive connection between the level of service and the satisfaction of students. Therefore, this explains the satisfaction of the whole students with the efficiency of the services provided by the university.

In addition, Thien and Jamil's (2020) study explored the impact of experience quality variables on the overall satisfaction of 315 undergraduate students at a research university in Malaysia. 
The results showed good teaching, specific objectives and expectations, sufficient workload and effective evaluation have important effects on the overall satisfaction of students. The results presented empirical evidence to advise university agencies in adapting towell-planned courses to meet the needs and satisfaction of students. A research conducted on 100 graduate students by Kadirova et al (2015) also showed that there is a positive relationship with student satisfaction with the three dimensions of service quality, namely physical quality, interactive quality, and corporate quality. Academic staff and non-academic staff need to be guided on the assigned roles by the results of the report. In order to meet the satisfaction of graduate students, this is critical in producing operational quality, accuracy of information and integrity of service.

Karna and Julin (2015) carried out a report on the satisfaction of staff and students regarding university facilities in Finland. The study found that primary university operations, such as testing and teaching facilities, possessed a greater effect than supportive facilities on the overall satisfaction of students and staff. In addition, the study also discovered that physical facilities are more important to both academics and students compared to general facilities in which library facilities are the best explanatory factor for overall satisfaction. In addition, the research found that students were contented with factors related to public space, comfortable learning atmosphere, laboratory, teaching facilities and accessibility to university. Finally, the overall findings of both groups in Finland showed that the variables correlated with the study and teaching practices had the greatest effect on students' satisfaction.

In addition, Yusoff et al (2015) found (12) twelve underlying variables in Malaysian higher education setting that significantly affect the satisfaction of students. Textbooks, tuition fees, student support facilities, efficient comfortable atmosphere, classroom environment, student assessment, learning experiences, lecture and tutorial facilitating goods, business processes, lecturer relationships, competent and receptive faculty, helpfulness of staff, reviews, and class sizes have major effect on the satisfaction of students The research further established that study year, study programme and semester grade have a major effect on facilities for student support and class size.

Another study by Hanssen and Solvoll (2015) found that the institution's prestige, the image of the university and the quality of facilities have a strong impact on the satisfaction of students. However, job opportunities donot significantly influence the satisfaction of Norwegian university system. In addition, the study found that auditoriums, social areas, and libraries are the physical variables that most strongly affect the satisfaction of students. Ali, et al (2016) described academic, non-academic, and access, reputation, and programme subjects as the superior factors affecting the satisfaction of students. A research by Chandra et al. (2019) defined the effect between the standard of service and student satisfaction. This research included a total of 1,000 students from (13) thirteen higher education institutions. The findings indicated that there is a relationship between the standard of service and the satisfaction of students. This research indicates that in order to increase student satisfaction, universities in Riau shall make changes to student records and class comfort.

Previous studies have also shown that the standard of service has no important relationship with student satisfaction (Mulyono et al., 2020; Osman \& Ashraf, 2019; Martirosyan, 2015; $\mathrm{Wu}, 2014)$. For example, the study by Mulyono et al (2020) analyses the impact on satisfaction and loyalty of the quality of services given to students. Participants in this study were Universitas Muslim Nusantara Al-seventh Washliyah's students, with a total of 312 students. 
The findings showed that the satisfaction of students was not important in mediating the association between the problems with programme and the loyalty of students.

Furthermore, a study conducted by Wu (2014) on 470 individuals at Casino X in Macau, China shows that service quality does not have a major relationship with customer satisfaction. This result is in line with the findings of a study conducted by Osman \& Ashraf (2019) on 310 students in Bangladesh when service quality has no important relationship with student satisfaction. Another research by Martirosyan (2015) explored the influence of selected service quality variables on the satisfaction of students in Armenia. Adequate curriculum and faculty resources were identified as the key factors of student satisfaction. Research also found the negative relationships with the satisfaction of students in graduate teaching assistants and teaching styles.

\section{Conclusion}

The value of student satisfaction in the literature of higher education has emerged with the continuous growth of higher education throughout the world. The empirical literature of higher education was examined in this paper with the goal of improving the current contribution of knowledge. The empirical results indicated that service quality influences the satisfaction of students in various settings of the study context. It is obvious that the dimensions of service quality are the most crucial element to the satisfaction of students. These dimensions include the quality of service which are the tangibles, reliability, responsiveness, assurance, empathy, teaching, administrative services, support services, internationalisation, campus infrastructure, classroom environment, security aspects, academic facilities, libraries, sports facilities, internet services, dormitories, canteens, human element, lecture, tutorial facilitating goods, non-human element, textbooks, tuition fees, blueprint service, core service, appropriate assessment, facilities, advisory services, curriculum, financial assistants, student support facilities, clear goals and standards, study costs, good teaching, appropriate workload, physical quality, interactive quality, corporate quality, learning environment, public spaces, campus accessibility, professional comfortable environment, student assessment, learning experiences, business procedures, social areas, auditoriums and libraries.

\section{References}

Abdullah, F. (2006). The development of HEdPERF: A new measuring instrument of service quality for the higher education sector. International Journal of Consumer Studies, 30(6), 569-581. http://doi.org/10.1111/j.1470-6431.2005.00480.x

Adinegara, G. N. J., \& Putra, P. S. E. (2016). Assessment of service quality in higher education: Case study in private university. International Journal Business Management Invent. 5, 82-88

Al-Haddad, S., Taleb, R. A., \&Badran, S. (2018). The impact of the education services quality on students' satisfaction: an empirical study at the business schools in Jordan. International Journal of Business Excellence, 14(3), 393-413.

Alhkami, A. A., \& Alarussi, A. S. (2016). Service quality dimensions and customer satisfaction in telecommunication companies. Asian Journal of Business and Management, 4(3). 117-126

Ali, F., Zhou, Y., Hussain, K., Nair, P. K., \&Ragavan, N. A. (2016). Does higher education service quality affect student satisfaction, image and loyalty? A study of international students 
in Malaysian public universities. Quality assurance in Education, 24(1), 70-94. http://doi.org/10.1108/QAE-02-2014-0008

Alsheyadi, A. K., \& Albalushi, J. (2020). Service quality of student services and student satisfaction: the mediating effect of cross-functional collaboration. The TQM Journal, 32 (6), 1197-1215

Alves, H., \&Raposo, M. (2007). Conceptual model of student satisfaction in higher education. Total Quality Management \& Business Excellence, 18(5), 571-588.

Annamdevula, S., and Bellamkonda, R. S. (2016). The effects of service quality on student loyalty: the mediating role of student satisfaction. Journal of Modelling in Management, 11(2), 446-462

Annamdevula, S. (2017). Relationship between service quality, satisfaction, motivation and loyalty: A multi-dimensional perspective. Quality Assurance Education, 25, 171-188.

Asaduzzaman, H. M., \&Rahman, M. (2013). Service quality and student satisfaction: a case study on private universities in Bangladesh. International journal of economics, finance and management sciences, 1(3), 128-135.

Barua, D., \& Uddin, M. S. (2021). Service Quality Dimensions of Higher Education Institutions and Students' Satisfaction: Bangladesh Perspective. International Journal of Social Science Studies, 9(2), 13-19.

Brochado, A. (2009). Comparing alternative instruments to measure service quality in higher education. Quality assurance in Education, 17(2), 174-190. http://doi.org/10.1108/09684889510093497

Chandra, T., Hafni, L., Chandra, S., Purwati, A. A., \& Chandra, J. (2019). The influence of service quality, university image on studentsatisfaction and student loyalty. Benchmarking:An International Journal, 26(5), 1533-1549. http://doi.org/10.1108/BIJ-07-2018-0212

Clewes, D. (2003). A student-centred conceptual model of service quality in higher education. Quality in Higher Education, 9(1), 69-85.

Douglas, J. A., Douglas, A., McClelland, R. J., Davies, J. (2015). Understanding student satisfaction and dissatisfaction: An interpretive study in the UK higher education context. Student Higher Education, 40, 329-349.

Elliott, K., \& Healy, M. (2001). Key factors influencing student satisfaction related to recruitment and retention. Journal of Marketing for Higher Education, 10(4), 1-11.

Elliot, K., \& Shin, D. (2002). Student satisfaction: An alternative approach to assessing this important concept. Journal of higher education policy and management,24, 197-209.

Gallifa, J., \&Batallé, P. (2010). Student perceptions of service quality in a multi-campus higher education system in Spain. Quality Assurance in Education, 18(2), 156-170

Hasan, H. F. A., Ilias, A., Rahman, R. A., \& Razak, M. Z. A. (2008). Service quality and student satisfaction: A case study at private higher education institutions. International Business Research, 1(3), 163-175.

Hassan, A. M., \& Kurt, A. (2019). The Relationship between Service Quality and Customer Satisfaction: Case Study of Education Sector in Mogadishu, Somalia. International Journal of Innovative Science and Research Technology, 4(9), 314- 325

Hassan, S., Shamsudin, M. F., Hasim, M. A., Mustapha, I., Jaafar, J., Adruthdin, K. F., \& Ahmad, R. (2019). Mediating effect of corporate image and students' satisfaction on the relationship between service quality and students' loyalty in TVET HLIs. Asian Academy of Management Journal, 24(1), 93-105.

Jain, R., Sinha, G., \&Sahney, S. (2011). Conceptualizing service quality in higher education. Asian Journal on quality, 12(3), 296-314. https://doi.org/10.1108/15982681111187128 
DEVELOPMENT

Vol. 11 , No. 1, 2022, E-ISSN: 2226-6348 @ 2022 HRMARS

Kadirova, N., Li-Chen, L., Chan-Yin-Fah, B., \&Poh-Kiong, T. (2015). Service quality and postgraduate student satisfaction: A pilot study. European Academic Research, 2(12), 15483-15505.

Kandie, H. K. (2018). Effects of Service Quality on Students' Satisfaction in Libraries in Kenya Using Servperf Model: Case of St Pauls' University in Kenya. Archives of Business Research, 6(1), 117-133. doi:10.14738/abr.61.382

Kara, A. M., Tanui, E., \&Kalai, J. M. (2016). Educational service quality and students' satisfaction in public universities in Kenya. International Journal Education Social Science, 10, 37-48.

Khan, N. R., \& Shaikh, U. (2011). Impact of service quality on customer satisfaction: evidences from the restaurant industry in Pakistan. Management \& Marketing, 9(2), 343-355.

Letcher, D. W., \& Neves, J. S. (2010). Determinants of undergraduate business student satisfaction. Research in Higher Education Journal, 6(1), 1-26

Lien, P. T. (2017). Training service quality and its effects on student satisfaction: Case of a Vietnam university. International Academic Research Business Social Science, 7, 99-110.

Lukic, V. R., \& Lukic, N. (2020) Assessment of student satisfaction model: evidence of Western Balkans, Total Quality Management \& Business Excellence, 31(13-14), 1506-1518, DOI: 10.1080/14783363.2018.1489227

Lupo, T. (2013). A fuzzy ServQual based method for reliable measurements of education quality in Italian higher education area. Expert Systems with Applications, 40(17), 70967110.

Manik, E., Sidharta, I. (2017). The Impact of Academic Service Quality on Student Satisfaction. Retrieved from https://mpra.ub.uni-muenchen.de/80878/

Mansori, S., Vaz, A. F., \& Ismail, Z. (2014). Service quality, satisfaction and student loyalty in Malaysian private education. Asian Social Science, 10, 57-66.

Mark, E. (2013). Student satisfaction and the customer focus in higher education. Journal of higher education policy and management, 35(1), 2-10. https://doi.org/10.1080/1360080X.2012.727703

Mulyono, H., Hadian, A., Purba, N., \&Pramono, R. (2020). Effect of Service Quality Toward Student Satisfaction and Loyalty in Higher Education. The Journal of Asian Finance, Economics, and Business, 7(10), 929-938.

Navarro, M. M., Iglesias, M. P., \& Torres, P. R. (2005). Measuring customer satisfaction in summer courses. Quality assurance in education, 13(1), 53-65. https://doi.org/10.1108/09684880510578650

Neupane, R., Devkota, M. (2017). Evaluation of the impacts of service quality dimensions on patient/customer satisfaction: A study of private hospitals in Nepal. International Journal Social Science Management, 4, 165-176

Osman, A. R., \& Ashraf, M. A. (2019). The mediating role of placement in service quality of education: from international students' perspective. Iranian Journal of Management Studies, 12(4), 531-558.

Owino, E. O. (2013). The influence of service quality and corporate image on customer satisfaction among university students in Kenya (Doctoral dissertation, KCA University).

Panda, T. K., \& Das, S. (2014). The role of tangibility in service quality and its impact on external customer satisfaction: A comparative study of hospital and hospitality sectors. IUP Journal of Marketing Management, 13(4), 53.

Parasuraman, A., Zeithmal, V. A., \& Berry, L. L. (1988). SERVQUAL: A multiple-item scale for measuring customer perceptions of service quality. Journal of retailing,64(1), 12-40. 
DEVELOPMENT

Vol. 11, No. 1, 2022, E-ISSN: 2226-6348 @ 2022 HRMARS

Prakash, G. (2018), Quality in higher education institutions: insights from the Literature. The TQM Journal, 30(6), 732-748

Quinn, A., Lemay, G., Larsen, P., \& Johnson, D. M. (2009). Service quality in higher education. Total Quality Management \& Business Excellence, 20(2), 139-152

Saleem, S. S., Moosa, K., Imam, A., \& Khan, R. A. (2017). Service quality and student satisfaction: the moderating role of university culture, reputation and price in education sector of pakistan. Iranian Journal of Management Studies, 10(1), 237-258.

Sharma, S., \& Al Sinawi, S. (2021). Organizational Performance Influenced by Academic Service Quality: An Investigation in Public Universities in Malaysia. Education Research International, 2021, 9

Suhami, M. Z. A., Talib, S. A., Bachok, S., \& Saleh, M. M. (2018). Service attributes, customer satisfaction and return usage: A case of Uber Malaysia. Journal of Tourism, Hospitality \& Culinary Arts, 10(2), 81-103.

Sultan, P., \& Wong, H. (2010). Performance-based service quality model: An empirical study on Japanese universities. Quality Assurance in Education, 18(2), 126-143

Teeroovengadum, V., Kamalanabhan, T. J., \&Seebaluck, A. K. (2016). Measuring service quality in higher education. Quality Assurance in Education, 24(2), 244-258.

Tegambwage, A. G. (2017). The relative importance of service quality dimensions: An empirical study in the Tanzanian higher education industry. International Research Journal Interdisciplinary Multidiscipline Studies, 3, 76-86.

Thien, L. M., \& Jamil, H. (2020). Students as 'Customers': unmasking course experience and satisfaction of undergraduate students at a Malaysian Research University. Journal of Higher Education Policy and Management, 42(5), 579-600.

Thomas, E. H., \& Galambos, N. (2004). What satisfies students? Mining student-opinion data with regression and decision tree analysis. Research in Higher Education, 45(3), 251269.

Turay, T., Shahzad, A., Altaf, M., Hussain, H., Habiba, U. (2017). The impact of perceived service quality of 'CIAC' visa service process technology on students' satisfaction. Journal Quality Technology Management, 13, 61-83.

Uka, A. (2014). Student satisfaction as an indicator of quality in higher education. Journal of education and instructional studies in the world, 4(3), 6-10.

Van Truong, H., Pham, C. H., Vo, N. H. (2016). Service quality and students' level of satisfaction in private colleges in Vietnam. International Journal Financial Research, 7, 121-128

Wael, T. (2015). Using servqual model to assess service quality and students' satisfaction in Pavia University-Italy. International journal Research, 24, 24-31.

$\mathrm{Wu}$, H.-C. (2014). The effects of customer satisfaction, perceived value, corporate image and service quality on behavioral intentions in gaming establishments. Asia Pacific Journal of Marketing and Logistics, 26(4), 540-565

Yusof, M., McLeay, F., Woodrue-Burton, H. (2015). Dimensions driving business student satisfaction in higher education. Quality Assurance Education, 23, 86-104 